\title{
Utilizarea mijloacelor de comunicare moderne în misiunea Bisericii Radioul - (10 ani de emisie pentru Radio Lumina)
}

\author{
Viorel VLĂDUCU*
}

Abstract: The Remote broadcasting of information was a human ideal from ancient times. The radiophony is of great social importance for the dissemination of culture and unification of souls, because it can address the whole world. The radio enters into the privacy of the individual that finds him at home. By air waves, the word of Gospel comes down from the pulpit and they penetrate the souls and consciences. After 1989, the Church was able to expand the scope of its mission. A Chruch's radio station brings into the radiophonic landscape a new nuance, that of the Christian spirituality. The Church must continue the process of adapting its message to modern means of communication to meet the wishes of the interested ones that want to know as many details related to spirituality and morality.

\footnotetext{
* PhD Candidate, Faculty of Orthodox Theology at „1 Decembrie 1918” University in Alba Iulia, Romania.
} 
Keywords: mission, communication, communication, teaching, radio.

\section{Radioul - mijloc de comunicare}

In era tehnologică în care trăim, informaţia a devenit o sursă de putere. Depinde însă cum este folosită: în rău sau în bine. Orice individ sau entitate este mai mult sau mai puţin confruntat cu o anumită poziţionare faţă de această problemă. În acest sens, nici Biserica nu face excepţie de la această chestiune. Cu siguranţă că, pornind de la misiunea ei, instituţia ecleziastică este obligată să folosească informaţia şi mijloacele multimedia şi de comunicare în masă doar într-un sens pozitiv.

Pentru început este important să subliniem faptul că despre mijloacele multimedia am întâlnit o interesantă definiţie la Tay Vaughan în lucrarea „Multimedia ghid practic”: ,,....multimedia reprezintă orice combinaţie de text, elemente de grafică, sunete, animaţie şi secvenţe video, care ajunge la dumneavoastră prin intermediul calculatorului sau al altor mijloace electronice. ...puteţi electriza centrii nervoşi ai gândirii şi ai acţiunii din minţile oamenilor. Când le oferiţi controlul interactiv asupra procesului, îi puteţi fascina. Multimedia fascinează ochiul, urechea, degetele şi, cel mai important creierul".

Interesant este că din toate organele unui trup uman, specialiştii susţin că auzul este ,,prinţul simţurilor”, prin , legăturile directe pe care le are cu imaginaţia, cu creativitatea, cu simţirea şi cu inteligenţa... de aceea, cercetătorii afirmă că, în general, nevăzătorii au posibilităţi mai mari să-şi dezvolte inteligența decât cei care nu aud"’2. Chiar dacă aceste lucruri nu au fost cunoscute de oameni la început, un lucru e sigur; ei au încercat să transmită informaţia la distanţă. Acest fapt a reprezentat un ideal al omului din cele mai vechi timpuri şi a fost realizat mai întâi de germanul Heinrich Hertz care a reuşit pentru prima dată în 1886 să demonstreze existenţa undelor electromagnetice. Şi astfel a început epoca radioului.

${ }^{2}$ Eugenia Grosu Popescu, Jurnalism radio, specificul radiofonic, Bucureşti, Edit. Teora, 1998, p. 15. 
În România, primul post de radio a luat fiinţă la 1 Noiembrie 1928, când s-a difuzat prima emisiune în limba română a Societăţii de Difuziune Radiotelefonică din România. Profesorul Dragomir Hurmuzescu a rostit, după acel memorabil „Alo, Alo, aici Radio Bucureşti”, cu ocazia inaugurării postului de radio românesc câteva cuvinte memorabile: „Să nu se creadă că radiofonia este o chestiune numai de distracţie. Radiofonia este de o mare importanţă socială, cu mult mai mare decât teatrul, pentru răspândirea culturii şi pentru unificarea sufletelor, căci se poate adresa la o lume întreagă, pătrunzând în coliba cea mai răzleaţă a săteanului”.

Dezvoltarea radiofoniei la noi în ţară cunoaşte ritmuri destul de lente, din cauza lipsei receptoarelor. Pe plan mondial s-au înregistrat noi succese în acest domeniu, prin descoperirea semiconductoarelor, în anul 1948, care a dus la reducerea considerabilă a volumului aparatelor şi a ridicat foarte mult calitatea emisiei şi recepţiei undelor radio.

Influenţa radioului în viaţa socială a fost una considerabilă încă de la început. Este de ajuns să subliniem că în anul 1938, preşedintele american Roosevelt, prin celebrele sale „Convorbiri la gura sobei”, avut un success nebănuit în demersul său politic ${ }^{3}$. De asemenea, în 30 octombrie 1938, milioane de ascultători ai postului American CBS au intrat în panică ascultând la radio o adaptare a romanului SF War of the Worlds, scris de H. G. Wells, în care se descria o invazie a marţienilor pe pământ. Cercetările ulterioare au stabilit încrederea multă pe care o au ascultătorii într-un mijloc de comunicare în masắ.

După ascensiunea televiziunii, rolul radioului a mai scăzut, însă el îşi are în continuare rolul de fi vocea care îţi vorbeşte în intimitate. Radioul este un teatru imaginar. Când 1000 de copii urmăresc, la teatru, o reprezentaţie cu „Albă ca Zăpada” toţi cei 1000 de copii

\footnotetext{
${ }^{3}$ Paul Dobrescu, Alina Bărgoanu, Curs - Mass media şi societate, SNSPA, Facultatea de Comunicare şi Relaţii Publice „David Ogilvy, Bucureşti, pp. 76-77. ${ }^{4}$ Ibidem, pp.138-143.
} 
văd aceeaşi Albă ca Zăpada. Dacă însă aceşti copii ar asculta la radio basmul Albă ca Zăpada, atunci fiecare ar transpune informaţiile primate în imagini vizuale, creându-şi astfel o imagine proprie despre Albă ca Zăpada. Radioul rămâne cel mai rapid mijloc de informare, din punct de vedere jurnalistic, iar din punct de vedere tehnic are putere de penetrare în cele mai îndepărtate zone cu ajutorul vechiului sistem de retransmitere prin satelit. Caracteristica definitorie a presei radiofonice este oralitatea. Jurnalistul de radio se adresează publicului, folosind cuvântul rostit, având menirea de a educa.

Astăzi, nu există loc în lume, oricât de îndepărtat, sau vreun petic de pământ rătăcit prin oceane, unde să nu ajungă undele radio. În prezent, la nivel mondial există aproximativ 45000 de posturi de radio, iar în eter nu mai domneşte niciodată liniştea absolută. În ţara noastră sunt peste 300 de staţii staţii radio.

\section{Radioul în misiunea Bisericii}

Radioul religios a fost încă de la apariţia lui un altfel de radio. Însă dacă pentru un post de radio laic au existat şi există universităţi unde tinerii se pot şcoli, pentru radiourile religioase nu putem vorbi de o situaţie asemănătoare. Este necesar ca mass-media să îşi formeze jurnalişti în domeniu teologic sau învăţământul teologic să îşi adapteze programa în vederea lărgirii posibilităţilor de specializare în domeniul comunicării.

Chiar dacă unele facultăţi de teologie şi-au deschis secţii de comunicare, totuşi este nevoie de o mai mare aplecare spre acest fenomen, întrucât jurnalistul creştin şi omul de radio, în special, trebuie să aibă calităţi extraordinare în ceea ce priveşte posibilităţile de exprimare, întrucât oricât de mică ar fi greşeala la un radio religios, consecinţele sunt foarte mari; tot ceea ce s-a construit până atunci se dărâmă repede.

Pornind de la această răspundere în a construi bine printr-un post de radio religios, unii teologi s-au poziţionat într-o anumită prudenţă în 
ceea ce priveşte misiunea Bisericii prin radio. Spre exemplu, părintele profesor Ilie Moldovan de la Sibiu, pornind de la textul din Mt 7, 6 unde se vorbeşte că cele sfinte nu trebuie date celor ce nu le pot înţelege, atrage atenţia asupra acestui aspect, adică trebuie făcută distincţia „între cele ce se pot transmite şi cele ce nu se pot transmite"s. Totuşi părintele profesor Moldovan consideră că prin radioul bisericii trebuie avut în vedere „restaurarea legii strămoşeşti în întreaga ei condiţie creatoare ... reconstrucţia culturii tradiţionale ortodoxe". Aşadar, este imperios necesar ca în redacţiile radiourilor religioase să existe specialişti atât din domeniul tehnic cât mai ales din domeniul teologic şi muzical.

Cât priveşte situaţia existentă în România, au apărut mai întâi posturi de radio neoprotestante (Vocea Speranţei, 1992; Vocea Evangheliei, 1993; Micul Samaritean, 1994). Au urmat apoi ortodocşii (Radio Trinitas obţine prima licență audiovizuală în 1996 şi emite din 1998) şi catolicii, prin Radio Maria ${ }^{7}$ Prezenţa Bisericii Ortodoxe Române în spaţiul audiovizual este asigurată în prezent de posturile de radio: Trinitas, radioul Patriarhiei Române, Renaşterea - postul de radio al Arhiepiscopiei Clujului, Reîntregirea - postul de radio al Arhiepiscopiei de Alba Iulia, Dobrogea - postul de radio al Arhiepiscopiei Tomisului, Lumina - postul de radio al Episcopiei Severinului şi Strehaiei şi Ortodoxia - la Braşov. Aşadar, în contextul nou de după 1989, Biserica şi-a lărgit sfera de misiune prin utilizarea radiolui, tot mai mulţi considerând că pe calea undelor, cuvântul Evangheliei pătrunde în suflete şi conştiinţe.

\section{Radio Lumina - 10 ani de emisie}

Radio „Lumina” este postul de radio al Episcopiei Severinului

\footnotetext{
${ }^{5}$ Pr. prof. univ. dr. Ilie Moldovan, Cuvântul lui Dumnezeu şi mass-media, în vol. Simpozionului „Biserica şi mass-media: complementaritate sau adversitate?”, Baia Mare, Edit. Universităţii de Nord, 2008, p. 80.

${ }^{6}$ Ibidem, p. 82.

${ }^{7}$ Pr. dr. Nicolae Dascălu, Parabola făcliei aprinse - comunicarea religioasă în era informaţională, Bucureşti, Edit. Basilica, 2012, p. 304.
} 
şi Strehaiei. Pe 23 aprilie 2005, de ziua Sfântului Mare Mucenic Gheorghe, purtătorul de biruinţă - Ocrotitorul Severinului, s-au auzit pentru prima dată în eter programele acestui post de radio al Bisericii. Prima emisie a fost transmisiunea, în direct, a Sfintei Liturghii arhiereşti de la Catedrala Episcopală din Drobeta Tunu Severin, săvârşită de un sobor de arhierei, condus de ÎPS Teofan- Arhiepiscopul Craiovei şi Mitropolitul Olteniei. Acest post de radio este unul din mijloacele moderne de misiune ale Bisericii din Mehedinţi şi alături de revistele eparhiale şi paginile de Internet ale Episcopiei Severinului şi Strehaiei constituie un element important de prezentare a activităţilor bisericeşti, culturale şi sociale din Mehedinţi.

Acest post de radio a fost încă de la început un răspuns la o urgenţă imediată, aceea a dezvoltării instituţiilor de comunicare în masă ale Bisericii dar şi o întâmpinare a dorinţei credincioşilor din Mehedinţi de a avea posibilitatea de a cunoaşte cât mai multe din învăţătura de credinţă a Bisericii noastre ortodoxe. Postul de radio nu se află şi nu doreşte să fie în concurenţă cu celelalte organisme media de la orice nivel ar fi acestea, ci doreşte cooperare, în primul rând cu radiourile şi cu instituţiile mediatice ale Bisericii Ortodoxe.

La aniversarea a 10 ani de emisie, Părintele Episcop Nicodim afirma că ,prin sfintele slujbe şi prin emisiunile postului de radio Lumina, ascultătorii din Drobeta Turnu Severin dar şi de departe, prin Internet, au fost mai aproape de Dumnezeu".

\section{Radio Lumina - glăsuitor al Sfintelor Slujbe}

Programul radioului are drept repere esenţiale cele două transmisiuni directe zilnice de la Paraclisul Catedralei Episcopale, şi anume: dimineaţa - Utrenia şi Sfânta Liturghie iar seara - Vecernia. Astfel, radioul face posibilă participarea, într-o oarecare măsură la Sfânta Liturghie a persoanelor care nu se pot deplasa, transmiţându-se continuu o încurajare a oamenilor singuri şi lipsiţi de ajutor.

Aceasta reprezintă, aşa cum afirma Părintele Patriarh Daniel, o 
nouă formă de ajutor pe care Biserica, prin radio, îl acordă persoanelor care, din cauza bolilor, a vârstei înaintate, a distanţei foarte mari sau a problemelor care afectează evoluţia firească a vieţii, nu pot lua parte, de fiecare dată, la slujbele oficiate în lăcaşul de cult. De asemenea, după cum sublinia şi Prea Sfinţitul Părinte Episcop Nicodim, pentru orice creştin, ascultarea slujbelor la radio este o mângâiere duhovnicească, dându-se ocazia celor bătrâni sau bolnavi să asculte slujba şi să se roage chiar de acolo de unde se află.

\section{Radio Lumina - promotor de evenimente unice}

Radio Lumina a încercat să reflecteaze teologic şi spiritual momentele solemne din viaţa comunităţilor creştine din Mehedinţi. Pe parcursul anului 2006 s-a achiziţionat aparatură de sonorizare profesională, cu ajutorul căreia ascultătorii se pot bucura de transmiterea, în direct, a Sfintelor Slujbe şi a unor evenimente religioase din viaţa Eparhiei. Din multe parohii din judeţul Mehedinţi s-a transmis Sfanta Liturghie arhierească, săvârşită cu prilejul unor momente importante din viaţa respectivei comunităţi.

Într-o vreme în care valorile poporului român se diluează, evenimentele-simbol ale poporului român trebuie trăite cu solemnitate şi recunoştinţă. De aceea, prin buna colaborare cu celelalte radiouri creştin-ortodoxe din ţară s-a reuşit transmiterea pe postul de radio a unor evenimente importante din viaţa Bisericii Ortodoxe: întronizări de ierarhi, slujbe cu prilejul unor hramuri sau evenimente bisericeşti importante.

\section{Radio Lumina - promotor al valorilor neamului românesc}

Făcând cunoscute bogăţiile patrimoniului cultural-bisericesc românesc, Radio Lumina promovează şi o educaţie a publicului în sensul cunoaşterii şi preţuirii operelor de reală valoare spirituală şi culturală. Acest fapt are drept finalitate conştientizarea, de către preoţi şi credincioşi, a necesităţii conservării şi restaurării monumentelor 
şi obiectelor de patrimoniu. Prin programele radioului se încearcă afirmarea valorilor Ortodoxiei şi ale spiritualităţii româneşti în context local. Toate cuvintele rostite cu responsabilitate pe postul de radio vin să înnobileze sufletul şi să-l determine la o mişcare continuă spre Biserică, acolo unde este Hristos. Putem asemăna radioul cu un clopot, pe care chiar dacă nu-1 putem privi, îl putem totuşi auzi. El ne cheamă la o viaţă de obşte, la o viaţă în Hristos, pentru viaţa cea veşnică. Înţelegem astfel rolul misionar modern extrem de important al radioului. Se observă cu uşurinţă tendinţa lumii de azi de a acorda atenţie lucrurilor şi principiilor fără valoare. Radio Lumina acordă atenţie adevărului şi vieţii netrecătoare, care trebuie apreciate ca daruri de la Creator şi care pacifică sufletul în profunzimea lui. Informaţia prezentată în programele radioului este lipsită de obsesia comercială pentru senzaţional, cuvântul fiind unul prietenos şi cald, mai ales pentru cei singuri sau suferinzi. Pe 90,4 FM ascultătorii se mângâie şi se întăresc în credinţă prin ascultarea marilor duhovnici şi ierarhi care aruncă sămânţa cuvântului în inimile tuturor.

\section{Radio Lumina - punte de legătură cu românii din diaspora}

Din data de 23 aprilie 2006, programele radioului pot fi ascultate şi pe Internet, pe două benzi audio( $24 \mathrm{~K}$ bits/s - low şi $96 \mathrm{~K}$ bits/s - high). Sunt deja foarte mulţi români din întreaga lume care recepţionează Radio Lumina prin Internet şi care apreciază în mod deosebit cateheza pe care o primesc prin emisiunile Radio Lumina, informaţiile referitoare la viaţa spirituală a comunităţilor mari şi mici din Mehedinţi. Toate acestea au darul de a-i apropia şi mai mult de cei dragi rămaşi acasă. De la lansarea paginii de Internet, mii de vizitatori au ascultat programele de radio, cei mai mulţi apreciind eforul şi iniţiativa existentă la nivelul Eparhiei noastre, venind însă de multe ori şi cu observaţii pertinente de îmbunătăţire a emsiunilor, programelor şi buletinelor de ştiri. Feedback-ul dat de ascultători îi motivează pe ostenitorii postului de radio, înţelegând că mesajul adus pe calea undelor a ajuns la destinaţie. 


\section{Radio Lumina - lucrare benevolă pentru slujirea oamenilor}

Activitatea redacţională este susţinută de numeroşi colaboratori: teologi, scriitori, profesori, medici, jurişti, folclorişti, muzicologi, artişti, profesori, copii, elevi, studenţi, funcţionari publici. Postul de radio are o strânsă colaborare cu profesorii de religie din Drobeta Turnu Severin şi împrejurimi.

Este interesant de văzut cum oameni de diferite profesii îşi dau mâna pentru a participa activ în lucrarea misionară a Bisericii. În mod deosebit trebuie menţionată activitatea colaboratorilor noştri care lucrează voluntar la misiunea Bisericii. La Radio Lumina putem vorbi despre o misiune prin sunet şi cuvânt, adresată tuturor credincioşilor, spre folosul lor duhovnicesc, ca ajutor spre mântuire, toate acestea fiind împlinite spre slava Sfintei noastre Biserici.

Programele realizate de colaboratori promovează şi prelungesc misiunea Bisericii în dubla sa dimensiune: religioasă şi culturală. Grila de programe cuprinde emisiuni cu caracter religios, cultural, social, muzical şi informativ, emisiuni ce se doresc a fi spaţii de întâlnire dintre cuvântul lui Dumnezeu şi trăirile omului de azi. Se adaugă teme specifice fiecărei perioade liturgice a anului bisericesc, fiecărui post de peste an, fiecărei sărbători. Unele emisiuni sunt cu adresă specială pe grupe de vârste (copii, adolescenți) în care pe lângă teme specifice se promovează valorile moralei creştine. Se promovează o muzică selectă: simfonică, religioasă, ambientală dar nu sunt uitate nici tradiţiile şi muzica populară.

\section{Concluzii}

Biserica trebuie să continue procesul de adaptare a mesajului la mijloacele de comunicare moderne pentru a veni în întâmpinarea dorinţei celor interesaţi să afle cât mai multe amănunte legate de spiritualitate şi morală, constatându-se o creştere semnificativă a românilor preocupaţi de aspectul spiritual al vieţii, prin ascultarea unor programe la un post de radio al Bisericii. 


\section{Bibliografie}

1. Popescu, Eugenia Grosu, Jurnalism radio - specificul radiofonic, Bucureşti, Edit. Teora, 1998.

2. Dobrescu, Paul; Bărgoanu, Alina, Curs - Mass media şi societate, SNSPA, Facultatea de Comunicare şi Relaţii Publice „David Ogilvy, Bucureşti.

3. Dascălu, Nicolae, Parabola făcliei aprinse-comunicarea religioasă in era informaţională, Bucureşti, Edit. Basilica, 2012.

4. Moldovan, Ilie, Cuvântul lui Dumnezeu şi mass-media, în vol. Simpozionului „Biserica şi mass-media: complementaritate sau adversitate?", Baia Mare, Edit. Universităţii de Nord, 2008.

\section{Site-uri:}

1. www.radiolumina.ro

2. www.episcopiaseverinului.ro 